International Research Journal of Management, IT \& Social Sciences
Available online at https://sloap.org/journals/index.php/irjmis/
Vol. 5 No. 6, November 2018, pages: 52 59
ISSN: 2395-7492
https://doi.org/10.21744/irjmis.v5n6.338

\title{
Graham \& Dodd Theory in Stock Portfolio Performance in LQ 45 Index at Indonesia Stock Exchange
}

AA Sagung Istri Pramanaswari a
Gerianta Wirawan Yasa

2395-7492@ Copyright 2018. The Author. This is an open-access article under the CC BY-SA license (https://creativecommons.org/licenses/by-sa/4.0/) All rights reserved.

\section{Author correspondence:}

AA Sagung Istri Pramanaswari,

Master of Science in Accounting Progam at Udayana University, Indonesia

Email address: pramanaswari@gmail.com

\section{Introduction}

The development of the world of investment is now increasingly rapid, in which many people are interested in investing in the capital market. Based on the official website of the Indonesia Stock Exchange (IDX) and the Indonesian Central Securities Depository (KSEI), the number of new capital market investors up to December 31st, 2016 rose by 105.97 percent to 894,116 Single Investor Identification (SID) from the previous 434,107 SID on 31 st

\footnotetext{
a Udayana University, Faculty of Economics, Denpasar, Indonesia

b Udayana University, Faculty of Economics, Denpasar, Indonesia
} 
December 2015. This shows that the capital market has become an option for investors in placing excess funds in the hope of getting better returns compared to conventional financial instruments such as deposits or savings. The increasing public interest in investing in the capital market shows that Indonesian people are increasingly aware of the importance of investment.

Prior to deciding to invest in stock investors should analyze the stock valuation first to determine the intrinsic value of a stock. The stock valuation that produces intrinsic value information will then be compared with stock market prices to determine the position of selling or buying a company stock (Tandelilin, 2010: 301). The selling strategy will be carried out if the stock price is considered too expensive and exceeds its intrinsic value (overvalued) and a buying strategy will be carried out if the stock price is still considered cheap compared to its intrinsic value (undervalued).

The approach to assessing investment was first popularized by Ben Graham and David Dodd, which was then successfully adopted by value investors such as Warren Buffett, William J. R, Irving Kahn, Charles Brandes and others (Truong, 2009). The theory of Graham \& Dodd (1934) suggests that if investors buy stocks at prices below their intrinsic valued or undervalued, the stock price will rise to close to its intrinsic valued, and if investors buy shares at a price above intrinsic valued or overvalued, the stock price will fall close to its intrinsic valued. The intrinsic assessment process that is most widely used in scientific research is the approach to using fundamental analysis using Price Earning Ratio (PER). The PER approach uses an assessment based on the value of the PER of a stock, whereas in this study uses the Capital Asset Pricing Model (CAPM) which will measure a stock that is classified as overvalued or undervalued based on its position on the Security Market Line (SML).

CAPM or Capital Asset Pricing Model was pioneered by Sharpe, Lintner, and Mossin in 1964-1966. The CAPM model was awarded the Nobel Prize in 1990 and is often used to determine the value of equity cost. According to Bodie et al., (2014: 355) the CAPM model provides a precise prediction of how the relationship between expected risk and return is. Tandelilin (2010) states that the CAPM is a model that links the level of expected return of a risk asset with the risk of an asset in a balanced market condition. CAPM is used to estimate the return of a security and analyze the relationship between the return and risk. The aim of CAPM is to determine the minimum rewards expected results (required rate of return) from risky investments, because in a balanced situation it will be affected by the risk of the shares.

The measurement of overvalued stock portfolio and undervalued stock portfolio performance of the formation period was done after 6 month and 12 month know whether its performance moves in accordance with Graham \& Dodd's theory. The research which is conducted by Basu (1977), Fama and French (1992) found that the performance of undervalued stock portfolios will increase in the next period in the US capital market. Wiagustini (2010), Dewi et al., (2017), found that there was an increase in undervalued portfolio return in the next period and there was a decrease in overvalued portfolio return in the next period in the Indonesia Stock Exchange. However, this was not proved by the research which is conducted by Wardjono (2010) in which the results showed that undervalued stock portfolios decreased stock prices in the next period so that the average stock return is negative. While overvalued stock portfolios experience price increases in the next period. Therefore, it is very interesting for researchers to confirm Graham \& Dodd's theory in the performance of overvalued and undervalued stock portfolios in stocks listed on the LQ45 Index in the period February 2016 - July 2016 and February 2016 - August 2017. This underlies the research on "Theory of Graham \& Dodd in the Performance of the Stock Portfolio on the LQ45 Index on the Indonesia Stock Exchange ".

\section{Literature Review}

The theory proposed by Graham \& Dodd (1934) suggest that if investors buy shares at prices below their intrinsic or undervalued value, the stock price will rise to close to its intrinsic value, and vice versa, if investors buy stocks at a price above intrinsic or overvalued, the stock price will fall close to its intrinsic value. The basic idea is that if each stock is bought at a price below its intrinsic or undervalued value, then the entire portfolio is a good portfolio and will generate to return along with the increase in the value of the stock component close to its intrinsic value.

\section{Portfolio Theory}

The basic principle of portfolio theory expressed by Markowitz (1952), is not to "put all your egss in one basket" this principles do not invest all of the funds in just one stocks. Markowitz (1952), shows that when a person adds an asset to his investment portfolio, the total risk of the portfolio will decrease but the expected return will remain the

Pramanaswari, A. S. I., \& Yasa, G. W. (2018). Graham \& Dodd theory in stock portfolio performance in LQ 45 index at Indonesia stock exchange. International Research Journal of Management, IT and Social Sciences, 
weighted average of the expected return of each asset in the portfolio, in other word diversification will reduce total risk without sacrifice return.

\section{Materials and Methods}

In this section before presenting the research method, a literature review and hypothesis were presented as a part of the research method that will be applied in this research.

\section{Research Hypothesis}

\section{Overvalued Stock Portfolio Performance after 6 months and 12 months}

The theory proposed by Graham \& Dodd (1934) reveal that if investors buy stocks at a price below the intrinsic value or undervalued, the stock price will rise close to its intrinsic value, and vice versa if investors buy shares at a price above the intrinsic value or overvalued stock prices will fall close to their intrinsic value. Overvalued stocks should be sold because most likely in the future there will be a market correction. It can be caused by an overreaction of investors to a certain information and investors who tend to set too high prices for information that is considered good however tend to set price too low for information that is considered bad. This phenomenon reverses when the market realizes that it is overreacting as indicated by a decline in the performance of stocks that are classified as overvalued. This is consistent with the results of research by Wiagustini (2008), Chopra et al., (1992), and Nam et al., (2001) Therefore it can be formulated the hypothesis is:

H1: There is a decrease in the performance of the overvalued stock portfolio after 6 months and the following 12 months in accordance with Graham \& Dodd's Theory.

\section{Undervalued Share Portfolio Performance after 6 months and 12 months}

The theory of Graham \& Dodd (1934) reveals that if investors buy stocks at a price below the intrinsic valued or undervalued, the stock price will rise close to its intrinsic value, and vice versa if investors buy shares at a price above the intrinsic value or overvalued stock prices will fall close to their intrinsic value. Undervalued stocks should be bought or maintained because it is likely that in the future there will be a surge in stock prices. This can be caused by an overreaction of investors to information and investors who tend to set too high prices for information that is considered good and however they tend to set prices too low for information that is considered bad. This phenomenon is reversed when the market realizes that it is overreacting, which is indicated by rising prices that are classified as undervalued. This is consistent with the result of research conducted by Knopers (2014) in the Dutch capital market the result show an undervalued stock portfolio resulting in a growth in stock price of $9.55 \mathrm{x}$ compared to the previous period. The researchers conducted by Basu (1977), Fama and French (1992) found that the performance of undervalued stock portfolios will increase in the next period in the US capital market. Wiagustini (2008) also found that there was an increase in undervalued portfolio returns in the next period on the Indonesia Stock Exchange. Therefore, the hypothesis can be formulated as follows:

$\mathrm{H} 2$ : There is an increase in the performance of the stock portfolio undervalued 6 months and 12 months in accordance with Graham \& Dodd's Theory.

\section{Research Design}

This study analyzes the performance of the overvalued and undervalued stock portfolio information period compared to the period after the formation in order to able to find out whether its performance is moves in accordance with Graham \& Dodd's Theory. The variables in this study were obtained through theoretical and empirical studies from previous studies. Through the study, it was obtained the problem formulation and research hypothesis. Before was able to be obtained testing statistical data, research samples, data types, and data sources must be determined first. Then the hypothesis was tested by using the Willcoxon test. After obtaining the result, it is interpreted to answer the formulation of the problem in this study so that a research conclusion can be obtained. 


\section{Research Methods}

This research was conducted in the Indonesia Stock Exchange (IDX) by accessing the website www.idx.co.id, in order to obtain the stocks listed in the LQ45 Index by taking down the information on the daily closing of the stock price of the LQ45 index for the period February 2016 - July 2016. In this study, it measured the performance of the overvalued and undervalued stock portfolio 6 months later and 12 months later, and measures the performance of the undervalued stock portfolio for the next 6 months and the next 12 months for the stocks listed on the LQ45 index for the period February - July 2016. Comparison of portfolio performance will be measured by using the Sharpe Index.

The data in this research are collected by taking down the data from daily stock prices in LQ45. The sample is selected by using purposive sampling technique. Purposive sampling is a uses in a collecting data technique with certain considerations or criteria (Sugiyono, 2013). The criteria used in selecting the samples in this research can be explained as follow:

a) The average value of expected return (positive return) of chosen company must be positive during the observation period

b) There will be 8 stocks chosen as a sample to be included in the portfolio by using CAPM approach. The classification of overvalued stocks is based on a comparison between the level of stock return expectations that CAPM requires from individual stock returns. If the expected return required by the CAPM is greater than the individual stock return, it means the share in the overvalued stock category, while those that have the highest individual stock return value of the expected return are required by the CAPM in the undervalued stock category.

\section{Variable Operational Definition}

The operational definition of variables is an explanation and theoretical understanding of variables to be observed and measured. In this study the operational definition which is being examined are:

a) The performance of overvalued stock portfolio after 6 months is the value of Sharpe index overvalued stock portfolio formed through eight shares with the CAPM method for the period February 2016 - July 2016 in the LQ45 index.

b) The performance overvalued stock portfolio performance after 12 months is the value of Sharpe index overvalued stock portfolio formed through eight shares with the CAPM method for the period February 2016 January 2017 in the LQ45 index.

c) The performance of undervalued stock portfolio after 6 months is the value of Sharpe index undervalued stock portfolio formed through eight shares with the CAPM method for the period February 2016 - July 2016 in the LQ45 index.

The performance of undervalued stock portfolio after 12 months is the value of Sharpe index undervalued stock portfolio formed through eight shares with the CAPM method for the period of February 2016 - January 2017 in the LQ45 Index.

\section{Results and Discussions}

The selection of 8 overvalued stock portfolio can be seen from the biggest difference in the expected return on the CAPM from individual stock returns. While the selection of undervalued stocks is based on the comparison between the rates of return or individual stock returns that are bigger than the stock return expectations required by CAPM Based on the calculation of the determination of the portfolio overvalued and undervalued the formation period with the CAPM method can be seen in Table 1 below:

Pramanaswari, A. S. I., \& Yasa, G. W. (2018). Graham \& Dodd theory in stock portfolio performance in LQ 45 index at Indonesia stock exchange. International Research Journal of Management, IT and Social Sciences, 5(6), 52-59. https://doi.org/10.21744/irjmis.v5n6.338 
Table 1

Overvalued portfolio forming using CAPM

\begin{tabular}{clcc}
\hline No & & Stock Code & $\begin{array}{c}\text { Overvalued } \\
(\mathrm{Ri})<\mathrm{E}(\mathrm{Ri})\end{array}$ \\
\hline 1 & BBRI & $-0,0007$ \\
2 & BMRI & $-0,0006$ \\
3 & PTPP & $-0,0004$ \\
4 & MPPA & $-0,0003$ \\
5 & LPKR & $-0,0001$ \\
6 & LSIP & $-0,0001$ \\
7 & BBNI & $-0,0001$ \\
8 & SRIL & $-0,0001$ \\
\hline
\end{tabular}

Table 2

Undervalued portfolio forming using CAPM

\begin{tabular}{clc}
\hline No & Stock Code & $\begin{array}{c}\text { Undervalued } \\
(\mathrm{Ri})>\mathrm{E}(\mathrm{Ri})\end{array}$ \\
\hline 1 & ANTM & 0,0074 \\
2 & PTBA & 0,0065 \\
3 & ADRO & 0,0057 \\
4 & INCO & 0,0044 \\
5 & MNCN & 0,0041 \\
6 & WSKT & 0,0037 \\
7 & ASRI & 0,0035 \\
8 & BBTN & 0,0028 \\
\hline
\end{tabular}

Ranking Description of Overvalued and Undervalued Portfolio Performance

Table 3

Summary of average performance of undervalued stock portfolio index and overvalued stock portfolio at LQ45 Index

\begin{tabular}{clc}
\hline No & \multicolumn{1}{c}{ Stock Portfolio } & $\begin{array}{c}\text { Sharpe Index } \\
\text { Performance }\end{array}$ \\
\hline 1 & Overvalued Stock Portfolio 6 months later & $-0,1470$ \\
2 & Overvalued Stock Portfolio 12 months later & $-0,8852$ \\
3 & Undervalued Stock Portfolio 6 months later & 7,3160 \\
4 & Undervalued Stock Portfolio 12 months later & 3,5430 \\
\hline
\end{tabular}

Based on Table 3, it can be seen that there was a decrease in the performance of the overvalued stock portfolio after 6 months is -0.1470 and a decrease in the performance of the overvalued stock portfolio after 12 months is -0.8852 . The results of this study indicate that $\mathrm{H} 1$ is accepted, there was a decrease in the performance of the overvalued stock portfolio after the period of portfolio formation after 6 months and 12 months in accordance with Graham \& Dodd's theory.

The increase in the performance of the stock portfolio was undervalued after 6 months amounting to 7, 3160 and an increase in undervalued portfolio performance after 12 months is 3,5430. The results of this research indicate that $\mathrm{H} 2$ is accepted, there was an increase in the performance of undervalued stock portfolios after the period of portfolio formation after 6 months and 12 months in accordance with the theory of Graham \& Dodd. 


\section{Conclusion}

a) There is a decline in the performance of the overvalued stock portfolio 6 months and the next 12 months based on Graham \& Dodd's theory.

b) There is an increase in the performance of the stock portfolio undervalued after 6 months and the next 12 months based on Graham and Dodd's theory.

\section{Suggestion}

Based on the conclusions stated, the following suggestions can be prepared:

a) For investors and investment managers, the results of this research indicate that compiling an overvalued stock portfolio after 6 months and 12 months on the LQ45 index shows a decrease in performance in accordance with Graham \& Dodd's theory. There was an increase in the performance of undervalued stock portfolios after 6 months and 12 months in the LQ45 index based on Graham \& Dodd's theory. It can be suggested that the selection of stocks in the portfolio may from stocks in different stock groups of other indices such as the IHSG, sectoral index, and Kompas100 Index.

b) This study diversified the stocks that are incorporated in the LQ45 index on the Indonesia Stock Exchange and measured the performance of the stock portfolio for the next 6 months and 12 months. Further research can establish an overvalued and undervalued portfolio with other methods such as PER, Arbitrage Pricing Theory (APT), Top Down Analysis (Three Step Approach) and Bottom-Up Analysis (Stock Picking). In addition, may IHSG as a comparison of the stock portfolio and choosing stocks of a combination of different stock groups from other indices such as the IHSG, the sectoral index, and the Kompas100 Index.

\section{Conflict of interest statement and funding sources}

The authors declared that they have no competing interest. The study was financed by themselves.

\section{Statement of authorship}

The authors have responsibility for research conception and design. The authors have approved the last article.

\section{Acknowledgments}

The authors thank the editor of IRJMIS for their support, valuable time, advice, and accepted this article.

Pramanaswari, A. S. I., \& Yasa, G. W. (2018). Graham \& Dodd theory in stock portfolio performance in LQ 45 index at Indonesia stock exchange. International Research Journal of Management, IT and Social Sciences, 5(6), 52-59. https://doi.org/10.21744/irjmis.v5n6.338 


\section{References}

Basu, S. (1977). Investment performance of common stocks in relation to their price-earnings ratios: A test of the efficient market hypothesis. The journal of Finance, 32(3), 663-682.

Bodie, Z., Kane, A., \& Marcus, A. J. (2011). Investment and portfolio management. McGraw-Hill Irwin.

Chopra, N., Lakonishok, J., \& Ritter, J. R. (1992). Measuring abnormal performance: do stocks overreact?. Journal of financial Economics, 31(2), 235-268.

Dewi, I. G. A. A. O., \& Dewi, I. G. A. A. P. (2017). Corporate social responsibility, green banking, and going concern on banking company in Indonesia stock exchange. International Journal of Social Sciences and Humanities, 1(3), 118-134.

Fama, E. F., \& French, K. R. (1992). The cross-section of expected stock returns. the Journal of Finance, 47(2), 427465.

Graham, B., \& Dodd, D. (2008). Security Analysis: Foreword by Warren Buffett. McGraw-Hill Professional.

IDX. Website Resmi Bursa Efek Indonesia (Indonesia Stock Exchange).

Knopers, F. E. J. (2014). Value Investing: Evidence from the Dutch Stock Market (Master's thesis, University of Twente).

Markowitz, H. (1952). Portfolio selection. The journal of finance, 7(1), 77-91.

Nam, K., Pyun, C. S., \& Avard, S. L. (2001). Asymmetric reverting behavior of short-horizon stock returns: An evidence of stock market overreaction. Journal of Banking \& Finance, 25(4), 807-824.

Sugiyono. (2013). Metode Penelitian Bisnis (Pendekatan Kuantitatif, Kualitatif, dan R\&D). Bandung: Alfabeta

Tandelilin, E. (2010). Portofolio dan Investasi teori dan aplikasi. Yogyakarta: Kanisius, 8-9.

Wardjono, W. (2010). Analisis Faktor-Faktor yang Mempengaruhi Price to Book Value dan Implikasinya pada Return Saham (Studi Kasus pada Perusahaan Manufaktur yang Terdaftar di BEI). Dinamika Keuangan Dan Perbankan, 2(1).

Wiagustini, N. L. P. (2009). Profitabilitas strategi investasi kontrarian di Bursa Efek Indonesia. Jurnal Manajemen dan Kewirausahaan, 10(2), 105-114.

Wiagustini, N. L. P. (2010). Dasar-Dasar Manajemen Keuangan. Edisi Pertama. Denpasar: Udayana University. 


\section{Biography of Authors}

\begin{tabular}{|l|l||}
\hline AA Sagung Istri Pramanaswari was born on April 12nd, 1993. She completed her \\
Bachelor Degree at Bali State Polytechnic. In 2018, she finished her Master of Science \\
in Accounting Progam at Udayana University. I am interested in the Capital Market and \\
Entrepreneurship. \\
Email: pramanaswari@gmail.com \\
\hline Eniversity. \\
Email: geriwiya@yahoo.co.id \\
\hline
\end{tabular}

Pramanaswari, A. S. I., \& Yasa, G. W. (2018). Graham \& Dodd theory in stock portfolio performance in LQ 45 index at Indonesia stock exchange. International Research Journal of Management, IT and Social Sciences, 5(6), 52-59. https://doi.org/10.21744/irjmis.v5n6.338 